\title{
ROSCAs as a
}

Peer Smets

\section{source of housing}

finance for the

urban poor: an

analysis of self-help

practices from

Hyderabad, India ${ }^{1}$

\begin{abstract}
For the urban poor, housing finance from ROSCAs (rotating savings and credit association) is an alternative to conventional housing finance, which requires conventional collateral. Contrary to conventional housing finance, the creditworthiness of ROSCA participants is determined largely by social factors. Moreover, a link exists between ROSCA participation and house (or shack) ownership. Apart from obtaining short- to medium-term ROSCA finance, participation offers security for obtaining finance from, for example, moneylenders. Notably, auction ROSCAs offer cheaper housing finance than Indian housing finance corporations. The middle classes mainly use this finance, but the poor tend to obtain more expensive finance for incremental building.
\end{abstract}

\section{ROSCAs: an introduction}

ROSCAs are a world-wide phenomenon which can be traced in urban as well as rural areas and are known under different names, such as tanda in Mexico, susu in Ghana, and chit funds or chits in India (for a longer list of local names see Ardener, 1964). A ROSCA consists of a group of participants - women, men or even children - who deposit a daily, weekly or monthly fixed contribution in a common pot which is allotted in part or whole to each participant in turn. The way a ROSCA operates can best be illustrated with an example. In a ROSCA with twelve participants each pays $\$ 10$ a month to a common fund. The kitty of $\$ 120$ will be allocated to one member, who can share the

1. This paper is dedicated to Jan van der Linden and is based on a study of literature and research into housing finance for lower-income groups undertaken in Hyderabad, India in 1993-1994. This research was funded by the Dutch Ministry of Development Affairs and the Vrije Universiteit, Amsterdam. Furthermore, I am indebted to my assistants in the field, G. Ramalakshmi and M. Ramesh. I am also grateful to Dick Kooiman, Mayke Kaag, Alfons van Marrewijk, and members of the Mutual Group of the Amsterdam School for Social Science Research for giving comments on earlier versions of this paper. 
fund as well as the costs of the contributions with a partner. The allocation of the fund will be repeated on a monthly basis till all participants have received the kitty once. It could be said that the first receiver of the fund obtains a loan from all the other ROSCA participants, while the last receiver in the queue has been saving for the whole ROSCA cycle. All other participants alternate between the position of debtor and creditor. In other words, a ROSCA is a very personal intermediary between savers and borrowers where a give-and-take process is involved. The fund can be distributed by means of, for example, lottery, auction, seniority, negotiation, consensus, bribery or the decision of the organizer (Ardener, 1964; Bouman, 1978, p. 38; Smets, 1992, pp. 13-23; Srinivas and Higuchi, 1996, p. 214).

Of these allocation mechanisms two will be explained in more depth: the lottery and the auction. At the beginning of a lottery ROSCA, the allocation of the pot is decided by drawing chits with the names of the participants on them, or by drawing lots at every gathering to decide who will receive the fund. Once a participant has obtained the kitty, partaking in the lot-drawing is disallowed, but for the remaining period of the ROSCA cycle the payment of the contributions is still compulsory.

In an auction ROSCA, the participants who want to obtain the kitty have to offer a discount on the fund. The person offering the highest discount will receive the fund. If the kitty is $\$ 120$ and the highest discount offered is $\$ 40$, the winner of the fund will obtain $\$ 80$. The remaining amount of $\$ 40$ will be generally distributed among all members equally. After receiving the kitty, partaking in the auction during the same ROSCA cycle is not allowed. Moreover, all ROSCA participants share equally the remaining discount amount every month. An advantage of the bidding method is that it enables participants to influence the timing of when they obtain the fund.

ROSCAs are managed in either an authoritarian or democratic way. In an authoritarian ROSCA decisions and responsibility are in hands of the organizer(s) and in a democratic ROSCA the participants have to take care of the management and maintenance of the ROSCA. In general, ROSCAs operate in the informal financial sector, beyond official regulations and control of the central bank. However, in several countries the government intervenes and places some of the existing ROSCAs under the control of the central bank. This is the case in India where ROSCAs can become registered as non-banking financial institutions.

\section{Urban ROSCAs for housing finance}

Urban ROSCAs can be used for investing in shelter in economically developed market societies where they are popular among migrant groups such as Somalian women in the United Kingdom (Summerfield, 1995, p. 214) and Koreans in Los Angeles, USA (Light and Deng, 1995, p. 218). However, ROSCAs are also used for buying, constructing, or improving houses in lessdeveloped countries such as Ghana (Bortei-Doku and Aryeetey, 1995, p. 
87), Turkey (Khatib-Chahidi, 1995, p. 250), Pakistan (Van der Harst, 1983, p. 65-66) and Mexico (Vélez-Ibañez, 1983, p. 22).

ROSCA participants are generally free to decide how to spend the kitty, according to their own wishes and preferences. It is only a proportion of the people who allocate the fund for shelter purposes. This investment can take place in the urban areas, but the urban ROSCA funds can also be transferred to the rural areas to invest them there in, for example, shelter. It can be said that ROSCAs are a source of housing finance, as is shown by several case studies.

Mayoux and Anand (1995) describe five case studies of reeling labourers in Tamil Nadu (South India), who participate in an Indian ROSCA called a chit fund. Of the five, four labourers have participated in a previous chit fund and two have used the kitty for the improvement of their shelter. Three labourers have used the kitty of the current chit fund for their shelter or intend to do so (ibid. 193-194).

In a sample $(n=192)$ taken in slums with self-help housing in the Indian city of Hyderabad, it appeared that $43.9 \%$ of the sample used more than one source, frequently including chit funds, for the construction of their shelter. Moreover, chit funds are used as the only source by $9.3 \%$ of the slum population. Other single sources are friends, relatives and neighbours $(11.7 \%)$, employers $(3.8 \%)$, moneylenders/pawnbrokers $(7.9 \%)$, finance corporations $(1.4 \%)$, savings $(20 \%)$, gift and dowry $(0.3 \%)$, and retirement benefits $(1.7 \%)$ (Smets, 1996a, p. 31). To illustrate the use of chit funds as a source of housing finance two examples from Hyderabad will be given. The first example shows how only auction ROSCAs are used as the sole source of housing finance, while the second example indicates that the ROSCA is only one source of housing finance amongst others.

Raju (35) works as a construction labourer and makes an income of about Rs. $800^{2}$ per month. In 1984 he settled with his wife Padma (30) and their three children in a slum on the outskirts of Hyderabad. The local slum leader allotted a free plot on which they constructed a hut. However, the plot had to be levelled, for which a stone cutter had to be employed for Rs. 3000. A loan was taken out against interest of $5 \%$ per month from a close relative cum chit fund organizer. In 1994 the credit had still not been repaid and was looking more like a gift. In 1992 a house with brick walls and asbestos sheets was constructed for Rs. 6000 . The construction costs were paid through his participation, on Padma's behalf, in two auction chit funds with only female participants, which were organized by the same relative who had earlier provided a housing loan. Both chit funds have a monthly contribution of Rs. 312.50 to be paid for a period of 16 months. In reality, the actual payments are less because a share of 1/16 of the discount offered is due which should be in the range of Rs. 500-2500. In the first chit fund a kitty of Rs. 3000 was obtained in the 16th month. For the remainder of the finance for the construction of the new shelter participation in the second chit fund was started and another kitty of also Rs. 3000 was obtained in the first month of the cycle.

2. One Indian Rupee (Rs.) equals 0.033 US\$ (1993-1994). This household with an income of Rs. 800 per month belongs to the so-called Economically Weaker Sections which have a household income of less than Rs. 1250 per month. 
The second example of the use of chit funds for housing follows:

Ravi (30) and Joti (28) live with their three children in a pacca $^{3}$ house in a slum which is reasonably centrally located in Hyderabad. Ravi works as a welder and Joti is employed as an aya (caretaker) at the local hospital. Together they have an income of Rs. 1800 a month and belong to the low-income groups. ${ }^{4}$ In 1992 their pacca house was built, which replaced a hut. The construction costs were Rs. 50,000, which was mobilized from various sources: a gift of Rs. 10,000 from Joti's mother, an interest-free loan of Rs. 20,000 from Ravi's employer, Rs. 15,000 through participation in two auction chit funds with a month contribution of Rs. 500 each, and the sale of Joti's jewels for Rs. 5,000.

Both case studies show that ROSCAs can be used as a source of housing finance by slum dwellers. In addition to the auction ROSCA mentioned in the case studies other types of ROSCAs such as the lottery type can also be used for the construction or improvement of shelter. In the lottery ROSCA the total of a participant's contributions (savings) generally equals the size of the fund unless commission for the organizer has to be deducted.

As well as the allocation of the ROSCA fund in cash, there are also ROSCAs where the input is paid in kind, for example, building materials (for Indonesia see Ghate, 1992, p. 94). After the pooled building materials have been obtained, they can directly be used for construction. However, the building materials can also be stored till enough material is available for the improvement or construction of the house. The storage of building materials provides the opportunity that if in urgent need of cash the person concerned can sell the building materials in part or completely (BorteiDoku and Aryeetey, 1995, p. 87).

The rotating fund can also deliver a house as is the case in Grahamstown, South Africa. Here, twelve workers at Koch Ceramics are organized in a ROSCA in order to build their own housing. All participants pay their contribution, deducted from their salary, to a building fund that is used to construct a brick house for each participant in turn. The order of allocation is determined in advance. The scheme was at the time of the research still in progress. However, there is some fear that participants who have already obtained their house may drop out and default (Buijs and Atherfold, 1995, p. 67-68).

\section{Creditworthiness needed for co-operation in ROSCAs}

For credit taken out from housing finance corporations, and banks, conventional collateral - a regular and high enough income and material possessions - is often required. Figure 1 shows that for housing finance, shelter, possibly in combination with land, has to be mortgaged. There is a linkage between obtaining a housing loan and the ownership of a house.

3. A pacca house refers to a house made of concrete walls and a concrete roof.

4. The low income group (LIG) encompasses households with a household income of Rs 1251-2650 per month. When I speak of the urban poor the Economically Weaker Sections and the LIG are referred to unless it is specified that one of these groups is denoted. 


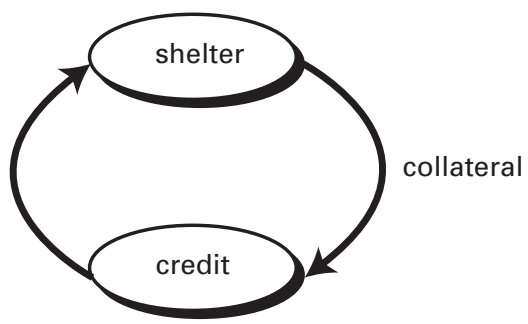

Fig. 1. Conventional mortgage

This section will show that the linkage between obtaining a housing loan and house ownership implies that ROSCAs are relevant either to shelter improvement or to the construction of a (second) house, generally bypassing tenants and shelterless people. For participation in registered chit funds, ${ }^{5}$ assured or secured income is especially important. They tend to accept mainly government employees and successful businessmen. When participants do not fall into this category they need a government employee as guarantor. The registration of the chit fund offers the possibility of filing a court case against defaulters.

The urban poor often lack conventional collateral, which can be mortgaged. However, the 'ROSCA (...) resolve the loan collateral and borrower information problems by enrolling only members who have mutual confidence in each other or by having organizers who guarantee the performance of individuals they enrol.' (Adams, 1992, p. 13). This refers to the democratic and authoritarian ROSCA respectively. Participants are carefully 'screened before their participation is accepted. Trust, acquaintance and social/cultural links are very important criteria for such screening.' (Srinivas and Higuchi, 1996, p. 214). Emphasis is put on non-conventional collateral, such as the borrower's character and proven behaviour in the past, which should be backed up by guarantors if possible.

In an urban setting it is rather difficult to select and screen ROSCA participants on the basis of non-conventional criteria. Urbanites are more mobile than rural settlers and can leave the neighbourhood where they work or live, or the city after they have obtained the ROSCA fund. In slums, occupant-ownership of a dwelling is required for being accepted as a ROSCA participant. An occupant-ownership status facilitates visibility for the other ROSCA peers and/or the organizer. In low-income neighbourhoods tenants are generally refused as participants in a chit fund. When they are accepted it can be very problematic, as is illustrated below with an example from Hyderabad:

'We accepted a tenant in our chit fund but he returned to his village of origin. It was difficult to trace his address, but finally we got it. When the chit started 
this member paid well, but the payments of contributions were soon delayed. If members do not pay in time we sometimes have to take out a loan with interest. We have to do this otherwise we will be blamed for not organising the chit in a proper way.'

Another chit fund organizer stressed the importance of the visibility of ROSCA participants.

'All members should have their own house in this neighbourhood. Tenants are not accepted, because we do not know if they will stay or leave the area.'

In exceptional cases, tenants may be accepted as ROSCA participants. A chit fund organizer explained:

'In our chit fund, owner-occupiers and tenants participate. Tenants are only accepted when there is no doubt that such a person has no plans to leave the neighbourhood. However, tenants are only allowed to obtain the fund at the end of the cycle.'

One possibility is for a landlord-cum-chit fund organizer to welcome his tenant as a ROSCA participant. To ensure trust close face-to-face contact is required. A landlord explained it as follows:

'I have helped my tenant by giving an amount (...) for meeting his immediate need or working capital (...) The tenant has returned back the amount on time. This favour has served as a starting point for the trust formation between us. As a result of this, his relatives are also started joining my chit. Further, when I landed in trouble, he has helped me to come out of the trouble by providing me loan through his relatives (...) Thus, this has helped me to develop helping network and thereby social wealth. This also helped me to manage the risk of default easily in case of members joined through my tenant.' (Radhakrishna and Galab, 1997, p. 118).

In exceptional cases, it is also possible for tenants to stick together and start their own ROSCA (Radhakrishna and Galab, 1997, p. 110).

Investment in a dwelling improves the creditworthiness of slum dwellers, which enables them to mobilize credit if required, and not necessarily housing finance, as illustrated by a slum dweller in Karachi:

'Everybody around knowns that I have spent Rs. 3000, on this house. So my neighbours know that I would not run away, and when my wife had to be admitted in the hospital, I could borrow from my neighbours.' (Van der Linden, 1983, p. 73).

It may be suggested that in order to participate in a ROSCA, collateral in the form of one's own shelter is required in an urban setting. This fits the idea of Hechter (1987, p. 110) that only people 'who are unlikely to leave the community' will be accepted as ROSCA participants. Figure 2 shows that shelter operates as collateral for participation in a ROSCA and through this participation finance can be mobilized for investing in the shelter. In addition, participation in a ROSCA can serve as collateral for obtaining a housing loan from, for example, a relative or moneylender. In that case the 


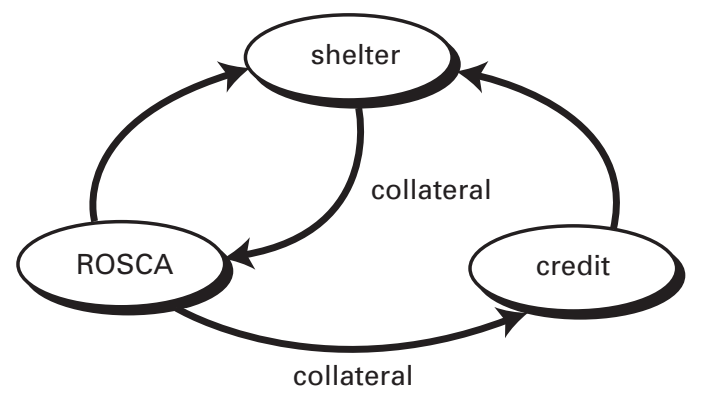

\section{Fig. 2. Shelter-ROSCA-credit model}

ROSCA fund, which has still to be received, is expected being used for the repayment of the credit taken out. This is especially possible if the loan can or has to be repaid in a lump sum (Van der Harst, 1983, p. 66).

Why is it that ROSCA participation is accepted as collateral for obtaining a loan? ROSCAs encourage the saving habit among their participants. Moreover, peer pressure or pressure from the organiser(s) to pay the contributions in time is strong and default rarely occurs. Sometimes the participants even have to sell or pawn goods to take out a loan in order to meet the obligations towards the ROSCA in which they participate. In extreme cases peer pressure in ROSCAs can lead to suicide when a participant cannot fulfil his financial obligations (e.g. Smets, 1992, p. 65-66).

The linkage between shelter ownership and ROSCA participation can be further developed. Some ROSCA participants use the fund to build an additional room and use the rent gained to pay the ROSCA contribution. In this way they can extend their house bit by bit and create more living space for the future when children are grown up or get married.

\section{Finance from auction ROSCAs and housing finance corporations in India compared}

In this section, housing finance from auction ROSCAs and private housing finance corporations will be compared. By comparing the characteristics it will be shown which options fit which income groups most. Housing finance mobilized through auction ROSCAs is short or medium-term finance. The maximum period of a ROSCA cycle is 50 months. Longer ROSCA cycles can be found with registered chit funds, but are not preferred due to their high default rates. Organizers of registered chit funds report that the optimal length of a cycle is maximum 20 months to maintain the social control mechanism.

Table 1 provides an overview of examples of financial transactions in different auction chit funds with a cycle of 50 months, in a specific month. In each chit fund 50 participants have to pay a monthly contribution of Rs. 
Table 1 Financing of auction chit funds

\begin{tabular}{|c|c|c|c|c|c|c|c|}
\hline $\begin{array}{l}\text { months/ } \\
\text { members }\end{array}$ & Contributions & $\begin{array}{l}\text { total } \\
\text { fund }\end{array}$ & $\begin{array}{l}\text { highest } \\
\text { discount }\end{array}$ & $\begin{array}{l}\text { amount } \\
\text { receivable } \\
\text { minus } \\
\text { discount }\end{array}$ & $\begin{array}{l}\text { profit of } \\
\text { organizer } \\
\text { ( } 5 \% \text { of } \\
\text { total } \\
\text { contributions) }\end{array}$ & $\begin{array}{l}\text { participants } \\
\text { share in } \\
\text { highest } \\
\text { discount } \\
\text { minus } \\
\text { profit } \\
\text { organizer }\end{array}$ & $\begin{array}{l}\text { monthly } \\
\text { contribution } \\
\text { after } \\
\text { deducting } \\
\text { share } \\
\text { discount }\end{array}$ \\
\hline 50 & 10,000 & 500,000 & 200,000 & 300,000 & 25,000 & 3,500 & 6,500 \\
\hline 50 & 5,000 & 250,000 & 112,500 & 137,500 & 12,500 & 2,000 & 3,000 \\
\hline 50 & 2,000 & 100,000 & 45,000 & 55,000 & 5,000 & 800 & 1,200 \\
\hline 50 & 1,000 & 50,000 & 23,000 & 27,000 & 3,000 & 400 & 600 \\
\hline
\end{tabular}

Based upon the economic research group (1993: 14)

10,000 , Rs. 5,000 , Rs. 2,000 or Rs. 1,000 , respectively. The example in the first row shows that the person who offers the highest discount (Rs. 200,000) for the fund of Rs. 500,000 will receive the fund minus the highest discount offered; Rs. 300,000. The remaining amount of Rs. 200,00 minus the profit margin of the organizer(s) will be divided among all participants, and can be deducted from the original contribution. In other words, each participant pays in practice less than the prescribed monthly contribution. For an overview of these amounts see the last column of Table 1. However, it should be realized that on account of the discounts offered the actual contributions can differ on a monthly basis. When many participants compete for obtaining the fund, the discount offered tends to be larger than when only a few want to receive that fund in that specific month. In this respect, "[i]t was said that those with lucrative sources of investment generally drew first, and those using the fund as a source of savings for such items as house improvement or dowry tended to draw last' (Mayoux and Anand, 1995, p. 186).

Private housing finance corporations are another source of individual housing finance; they offer loans of up to Rs. 25,000 with an interest rate of maximum $12 \%$ p.a. Loans of Rs. $25,001-100,000$ bear a maximum rate of $15.5 \%$ p.a., while the housing finance corporations are free to fix the interest rates for credit between Rs. 100,001 and Rs. 200,000. For upgrading loans up to Rs. 30,000 the maximum allowed interest is $15.5 \%$ p.a. and the term of the housing loans is $5-15$ years. By keeping the interest rates lower for the smaller loans it was thought that the poor could be served. The underlying assumption is that the poor will take out smaller loans (Smets, 1997, p. 3). However, housing finance corporations

'tend mainly to serve households with income above medium level, because the lending criteria (long-term credit, large loan size and tight methods of repayment) most closely fit the life style of this income group (...) The same lending criteria, except a lower interest rate, are used for the poor.' (Smets, 1997, p. 14).

The housing finance corporations tend to provide housing loans for complete dwelling units and the upgrading loans are more expensive than the 
regular housing loans which leads to a prioritization of credit for the construction of complete housing units.

In the Indian newspaper Deccan Chronicle an article was published by the economic research group (1993) which compared housing finance from housing finance corporations and auction ROSCAs. Table 2 provides an overview of the processing charges of housing loans of Rs. 200,000. These fees vary from Rs. 1,500 to Rs. 6,000 for the housing finance corporations, namely, HDFC, Indbank Housing Finance Ltd, AB Homes Finance Ltd, LIC Housing Finance Ltd, and Citi Homes Finance Ltd. Private land developers/dealers and chit funds do not charge processing costs. ${ }^{6}$ Housing loans with a term of 5 years, result in equated monthly instalments (EMI) of Rs. 249-269 for housing loans from private housing finance corporations, Rs. 250 for schemes for plots through private dealers and Rs. 184 for a chit fund. However, in comparison with the loan term of 5 years the chit fund covers only 50 months, which equals the length of the ROSCA cycle.

About chit fund financing the economic research group (1993, p. 14) wrote:

'It seems the traditional way of financing through chit funds is the cheapest way (...) However, chits are available for a maximum period of 50 months (...). However, this may suit people who are reaching superannuation date. (. . ) Chit fund financing is cheaper than' housing finance schemes of housing finance corporations and private plot dealers.

In general, chit funds with a large kitty require large monthly instalments, the size of which is also dependent on the length of the cycle and the number of participants. In chit funds with a high contribution, participation is restricted to middle or even high-income groups. The poor opt for chit funds with a smaller pot, which require smaller contributions, such as in the example of Raju and Padma, who have to pay a monthly contribution of Rs. 312.50 with bidding taking place on a pot of Rs. 50,000.

Small amounts of housing finance with a relatively short term are needed for incremental building, but incremental financing also enables incremental building. However, Malpezzi disagrees with the importance of the concepts incremental building and financing and argues that

\begin{abstract}
'very few households approach housing other than incrementally, in the sense of paying for their housing in parts, whether rich or poor households in rich or poor countries. What is desirable is to divorce incremental payment from incremental consumption, so that households can consume their desired bundle, or closer to it, sooner. (...) The existence of financial and rental intermediation implies that consumption decisions can be made less dependent on current income and more dependent on long run ('permanent') income, and long-run desired consumption.' (Malpezzi, 1994, p. 459).
\end{abstract}

In line with Malpezzi's argument long-term housing loans would be suitable for all income groups since one can enjoy the pleasure of a house now and

6. However, chit fund organizers may charge a fee for the management of the ROSCA. In registered chit funds a commission of $5 \%$ on the contributions is commonly charged. This $5 \%$ is divided among the organizer(s) (4\%) and the agent who has recruited that specific participant (1\%). 
Table 2 Housing finance schemes compared

\begin{tabular}{llc}
\hline Scheme & $\begin{array}{l}\text { processing charges for } \\
\text { Rs. 200,000 }\end{array}$ & $\begin{array}{l}\text { EMI for Rs. 10,000 } \\
\text { for 5 years }\end{array}$ \\
\hline HDFC & 1,600 & 258 \\
Indbank Housing & 1,500 & 258 \\
$\begin{array}{l}\text { AB Homes } \\
\text { LIC housing }\end{array}$ & 2,000 & 258 \\
$\begin{array}{l}\text { own your house scheme } \\
\text { non-policy linked scheme }\end{array}$ & 2,000 & 249,269 \\
$\begin{array}{l}\text { Citi homes } \\
\text { private dealers }\end{array}$ & & 269 \\
$\begin{array}{l}\text { instalment schemes for plots } \\
\text { chit fund }\end{array}$ & 6,000 & 250 \\
\hline
\end{tabular}

Source: Economic research group (1993: 14)

pay for it later. However, in practice this appears to fit the way the upper and middle classes construct and finance their houses. They can afford to cope with long-term financial obligations while after deduction of the loan instalments from their income enough money will still be left over to meet other felt needs.

The reason why the poor still opt for incremental building and financing is different from the logic of the middle and high-income groups. Due to an irregular and small income the poor are forced to build in an incremental way. They allocate financial and non-financial means to the construction and improvement of their shelter over a period of time. The moment when money can be used for housing is also dependent on the appearance of other pressing needs. Such an incremental way of building fits the survival strategies of the urban poor, which reflect 'the ways in which urban poor households organize their production and consumption activities to guarantee the maintenance of their members.' (Chant, 1991, p. 26). These strategies encompass short-term financial planning. The poor try to avoid long-term financial obligations and consequently long-term deduction from their meagre income, because it is extremely difficult if not impossible to judge if they will be capable of meeting these obligations. In addition, a long-term deduction leads to a postponement of other felt needs such as medical care, the marriage of a daughter and investment in social relations. Such items can only be postponed for a certain period. If this period is too long living conditions of the poor will worsen rather than improve.

Housing finance from housing finance corporations requires conventional collateral that is rarely available among the poor, who often reside in socalled slums. Housing loans taken out from housing finance corporations are generally used for the construction of complete dwelling units. Moreover, the smaller loans are not obtained by the low-income groups only, but also by the middle and high-income groups. Dependent on the size of the contributions and the length of the ROSCA cycle, ROSCAs offer access to 
housing finance both for complete units and for an incremental building process. In reality participation is especially open to middle-income groups, who will probably use the ROSCA as a source of housing finance, despite their short term and large contributions because it is cheaper. For the lowincome groups such comparisons are useless because they lack access to housing finance corporations. They are dependent on ROSCAs, or other sources in the informal financial sector, which offer them short- to mediumterm housing finance. For Hyderabad, this term is 5-6 years. Such a term facilitates their survival strategies and enables them to improve their living conditions step by step.

\section{ROSCAs and community development}

Lessons $^{7}$ for the creation of a community-based finance system in an urban low-income community can be derived from the operation and maintenance of ROSCAs in the so-called 'informal' financial sector. First of all, already existing ROSCAs should be strengthened in their operation and management, if required at all. When a ROSCA is non-existent among a specific urban community, an intervening agency may consider establishing a community-based finance scheme such as a ROSCA. It is advisable to consider in consultation with the target group why, how, and when which type of a community-based finance scheme can help the people concerned. This requires a lot of interaction with the target group, which should be strengthened at the grassroots. In this respect, it is advisable to train more people than only the community leader in the required skills. Moreover, it is important that the development of a community-based finance scheme such as a ROSCA takes place in a democratic and open way so that the rights and responsibilities of the participants are linked up. Herewith one should take into account that women are well known for their savings behaviour, good recovery records, and positive influence on their husbands' payment behaviour. In addition, women are often a decisive factor at time of social or financial stress when males opt for selling assets such as their house (Peltenburg, 1990). Only when all these factors are taken into account it is possible to work towards a more sustainable scheme in the long run.

When a development agency, in line with the above said, aims at the creation of community-based finance schemes to improve of the living conditions of the urban poor four points of attention will be provided. During the period of creation and management of a community-based finance scheme it is, first, important that the target group considers the scheme 'ours' and not 'theirs'. 'Theirs' may refer to anybody such as the government, NGOs, banks, and community leaders. A community-based finance scheme, considered 'ours' by its participants, has the potential of increasing the involvement of these participants in the development of a successful scheme. Due to welfare schemes the poor are often accustomed to the fact

7. Material for the discussion of lessons which can be derived from the operation and maintenance of community-based finance schemes is to a large extent taken from Smets (1996b) 
that all kind of aid will be provided free of costs. Moreover, loans involved will be often remitted in the future. These loans will be written off in a legal or illegal way. People will anticipate on these practices and credit taken out from a loan scheme will not be repaid promptly, if at all. This has to do with the perception the borrower has of the lender. In this connection the government and banks are often considered weak and unable to recover sufficient credit from the borrower (Menon, 1993, p. 6).

To create an 'ours' feeling it is important to have a period of pre-funding in which community development can take place. In such a period the target group should develop a savings and credit scheme in which only money of the participants is involved. Thrift amounts and credit derived from these savings may be viewed as 'ours' while matching grants or outside funding are viewed as 'theirs'. When the scheme is considered 'theirs', its participants probably go for grasping whatever they can grasp. They try to take the best advantage of it. However, when the scheme is considered 'ours' a community is more eager to preserve the scheme. A mutual understanding of all members repaying and saving in the scheme should be developed. Many borrowers are eager to pay if they are sure that all others are also paying. This requires financial transactions in an open and democratic way (Menon, 1993, pp. 6-8).

Second, once a community-based finance scheme has established a reputation of regular payment and sincerity of purpose it will keep out persons, who want to take advantage out of the scheme. The newly created norms and values of the community can be an effective weapon against unscrupulous persons (Menon, 1993, p. 9).

Third, peer pressure in ROSCAs is a powerful incentive to encourage participants to pay their contributions to the financial scheme in time. Peer pressure requires knowledge of the ROSCA participants whether they can be trusted. However, trust in the payment behaviour of other urban nonparticipants is rather difficult because in an urban context is it rather easy to escape peer pressure. For the sake of a proper community-based financial scheme it is of great importance that participating community members cannot escape control measures of peers. The chance to do so declines when the potential defaulters are tied to their place of living. This is exactly the situation when such members live in an own house.

Last but not least, it should be mentioned that finance is not 'the' solution for improving the living conditions of the poor in urban areas. It is a necessary but not a sufficient factor for the achievement of that end. Other factors such as education, and employment opportunities have to be part of it.

\section{Conclusions}

Among other financial sources, housing finance can be mobilized through ROSCAs, which combine savings and credit. The middle-income groups especially participate in ROSCAs with higher contributions, while the poorer sections choose ones with smaller amounts. For registered chit funds the 
participants need to have a regular and large enough income and often have to be backed up by a guarantor derived from their social network. In addition to these income criteria, the possession of a house is generally required for participation in non-registered ROSCAs. However, in slums shelter is often of an illegal nature and cannot easily, if at all, be mortgaged, but serves more as non-conventional collateral. Moreover, ROSCA participation can be used to secure the repayment of a loan borrowed from, for example, a relative or moneylender. In such a situation the ROSCA fund that will be received in the future is expected being used for the repayment of the loan.

Evidence suggests that incremental financing fits micro finance (small amount, short term, non-conventional collateral and unrestricted in use). Such housing finance as is derived from auction ROSCAs is cheaper than that through Indian housing finance corporations, who mainly serve the middle class. ROSCAs are also accessible for the poor and can support their practices of incremental building and financing, which is one of their survival strategies. In brief, what is implied all along is that ROSCAs can be an interesting option for mobilizing housing finance, but they are not the answer. ROSCAs can work for some people under certain conditions. To acquire ROSCA membership individuals usually have to be part of a social network and there should be some guarantee of its continuation, such as an owneroccupant status. Ownership-occupant status for slum dwellers ensures the visibility of the ROSCA participant and ensures the membership of a social network to a large extent. However, a social network should be maintained, for which (financial) means need to be invested. As a consequence of a shortage of means to invest in their social network the poorest of the poor tend to be excluded from ROSCA participation.

What does this case study on housing finance imply for community development in urban low-income neighbourhoods? First, before intervening, one should consider whether intervention is needed at all. In this, the quality of already operational community-based finance systems among the selected community has to be taken into account. When it is judged that intervention is required it is of great importance that the new systems do not destroy already existing successful ones. Second, for the sake of intervention it is crucial that participants in a community-based finance scheme have to be tied to their neighbourhood or a specific community. Here the beneficiaries have to be part of an established social network, where peer pressure minimizes escape behaviour or even free rider behaviour. Third, apart from social factors, more hard values such as an owner-occupant status, have to be incorporated in the process of community development in an urban low-income neighbourhood. Fourth, community development can only be successful when the norms and values used fit the survival strategies of the urban poor. When there is a mismatch between those norms and values, the poor are generally not helped at all. Lastly, community development can lead to the benefit of the entire community, but as a spinoff also for individual members. Here communication with others enables 
access to networks where help can be obtained. For ROSCAs this implies that individuals can use their participation in a community-based finance scheme for obtaining credit from others.

Peer Smets is lecturer at the faculty of social studies of the Vrije Universiteit, Amsterdam, where he is currently completing his Ph.D. on housing finance of low-income households in Hyderabad, India. He has published numerous articles on government bureaucracy, financial self-help organizations, housing finance and slum development in India and South Africa. Some of his recent articles are 'Private housing finance in India: reaching downmarket?' Habitat International (1997) 21(1): 1-15; 'Money-go-rounds for women. Finance as instrument or as ultimate goal in lottery ROSCAs.' Anthropos (1998) 93; (co-written with R. J. Baken) 'Better a "hut" on the ground than a castle in the air: formal and informal housing finance for the urban poor in India'. K. Datta and G. A. Jones (eds), Housing and Finance in Developing Countries (1999) London/New York: Routledge.

Address for correspondence: Peer Smets, Vrije Universiteit, Faculty of social studies, Department of cultural anthropology and development sociology, De Boelelaan 1081c, 1081 HV Amsterdam, The Netherlands. Tel: +31 20444 6742; Fax: +31 204446722 email: pgsm.smets@scw.vu.nl

\section{Bibliography}

Adams, D. (1992) Taking a fresh look at informal finance, in D. W. Adams and D. A. Fitchett, eds, Informal finance in low-income countries, Westview, Boulder, CO.

Ardener, S. (1964) The comparative study of rotating credit associations, The journal of the Royal Anthropological Institute of Great Britain and Ireland, Vol. 94, pp. 201-229.

Bortei-Doku, E. and Aryeetey, E. (1995) Mobilizing cash for business: women in rotating susu clubs in Ghana, in S. Ardener and S. Burman, eds, Money-gorounds; the importance of rotating savings and credit associations for women, Berg, Oxford, UK.

Bouman, F. (1978) Indigenous savings and credit societies in the Third World, Development Digest, Vol. XVI, No. 3, pp. 36-47.

Buijs, G. and Atherford, G. (1995) Savings and money-lending schemes: how rotating credit associations help poor families, Human Sciences Research Council, Pretoria, South Africa.

Chant, S. (1991) Women's work and household change in Mexico, in The revolution: the challenge of reform in Mexico, Tauris, London, UK.

Economic Research Group (1993) How to build your own dream house. Deccan Chronicle, Business Finance section, pp. 13-14, Monday September 20.

Ghate, P. (1992) Informal finance: some findings from Asia, Oxford University Press, Hong Kong.

Hechter, M. (1987) Principles of group solidarity, University of California Press, Berkeley, CA.

Khatib-Chahidi, J. (1995) Gold coins and coffee ROSCAs: Coping with inflation the 
Turkish way in Northern Cyprus, in S. Ardener and S. Burman, eds, Money-gorounds; the importance of rotating savings and credit associations for women, Berg, Oxford, UK.

Light, I. and Deng, Z. (1995) Gender differences in ROSCA participation within Korean business households in Los Angeles, in S. Ardener and S. Burman, eds, Money-go-rounds; the importance of rotating savings and credit associations for women, Berg, Oxford, UK.

Malpezzi, S. (1994) 'Getting the incentives right': a reply to Robert-Jan Baken and Jan van der Linden, Third World Planning Review, Vol. 16, No. 4, pp. 451-466.

Mayoux, L. and Anand, S. (1995) Gender inequality, ROSCAs and sectoral employment strategies: questions from the South Indian silk industry, in S. Ardener and $\mathrm{S}$. Burman, eds, Money-go-rounds; the importance of rotating savings and credit associations for women, Berg, Oxford, UK.

Menon, L. (1993) Urban Credit - UBSP Experience. Paper presented at workshop 'Composite Credit Mechanism for the Urban Poor', organized by Habitat Polytech, New Delhi. 16-18th November.

Niger-Thomas, M. (1995) Women's access to and control of credit in Cameroon: The Mamfe case, in S. Ardener and S. Burman, eds, Money-go-rounds; the importance of rotating savings and credit associations for women, Berg, Oxford, UK.

Peltenburg, M. (1990) Women and Low-income Housing Finance: A Different Perspective, VENA Newsletter: Women and the Urban Habitat, Vol. 1, No. 2, pp. 15-18.

Radhakrishna, R. and Galab, S. (1997) Informal mutual credit associations in India: a case study of slums in Hyderabad (draft). Centre for Economic and Social Studies, Hyderabad, India.

Smets, P. (1992) My stomach is my bishi: savings and credit associations in Sangli (India), Urban research working papers No. 30, Vrije Universiteit, Amsterdam, The Netherlands.

Smets, P. (1996a) Informal housing finance in Hyderabad, India. Urban research working papers, No. 40, Vrije Universiteit, Amsterdam, The Netherlands.

Smets, P. (1996b) Community-based finance systems and their potential for urban self-help in a new South Africa, Development Southern Africa, Vol. 13, No. 2, pp. 173-187.

Smets, P. (1997) Private housing finance in India: reaching down-market?, Habitat International, Vol. 21, No. 1, pp. 1-15.

Srinivas, H. and Higuchi, Y. (1996) A continuum of informality of credit: what can informal lenders teach us?, Savings and Development, Vol. XX, No. 2, pp. 207-221.

Summerfield, H. (1995) A note on ROSCAs among North Somali women in the United Kingdom, in S. Ardener and S. Burman, eds, Money-go-rounds; the importance of rotating savings and credit associations for women, Berg, Oxford, UK.

Van der Harst, J. (1983) Financing housing in slums, in J. W. Schoorl, J. J. van der Linden and K. S. Yap, eds, Between basti dwellers and bureaucrats: lessons in squatter settlement upgrading in Karachi, Pergamon Press, Oxford, UK.

Van der Linden, J. (1983) The squatter's house as a source of security, in J. W. Schoorl, J. J. van der Linden and K. S. Yap, eds, Between basti dwellers and bureaucrats: lessons in squatter settlement upgrading in Karachi, Pergamon Press, Oxford, UK.

Vélez-Ibañez, C. G. (1983) Bonds of mutual trust: the cultural systems of rotating credit associations among urban Mexicans and Chicanos, Rutgers University Press, New Brunswick, NJ. 